\title{
Synthesis and Characterization of Hydroxyapatite Derived from Milkfish Bone by Simple Heat Treatments
}

\author{
Jumiarti Andi Lolo ${ }^{1, *}$, Dian Pranata Putra Ambali ${ }^{2}$, Wilson Jefriyanto ${ }^{1}$, Dwi Handayani ${ }^{3}$, \\ Wiwik Afridah ${ }^{3}$, Edza Aria Wikurendra ${ }^{3}$, Rizki Amalia ${ }^{4}$, Achmad Syafiuddin 3,* (D)

\begin{abstract}
Department of Physics Education, Universitas Kristen Indonesia Toraja, Tana Toraja 91811, South Sulawesi, Indonesia Department of Civil Engineering, Universitas Kristen Indonesia Toraja, Tana Toraja 91811, South Sulawesi, Indonesia Department of Public Health, Universitas Nahdlatul Ulama Surabaya, Surabaya 60237, East Java, Indonesia Department of Midwifery, Universitas Nahdlatul Ulama Surabaya, Surabaya 60237, East Java, Indonesia
\end{abstract} \\ Correspondence: miaandilolo@ukitoraja.ac.id (J.A.L) achmadsyafiuddin@unusa.ac.id (A.S);
}

Scopus Author ID 57216968684; 56682128000

Received: 4.04.2021; Revised: 15.05.2021; Accepted: 18.05.2021; Published: 18.06.2021

\begin{abstract}
The present study aimed to synthesize hydroxyapatite (HAp) from milkfish (Chanos chanos) bone by simple heat treatments ranging from 600 to $800{ }^{\circ} \mathrm{C}$. The yield and color of synthesized powders before and after heat treatment were analyzed. The synthesized powders were characterized using Fourier transform infrared spectroscopy (FTIR) to identify the functional groups and X-ray diffraction (XRD) was employed to identify phase and crystallinity properties. This study found that the yield percentages were found to be approximately $50 \%$. The FTIR characteristics exhibited the phosphate and carbonate groups at high temperatures $\left(\geq 600^{\circ} \mathrm{C}\right)$. In general, this study confirmed that the wellcrystallized HAp can be synthesized by thermal treatment at a temperature of $160{ }^{\circ} \mathrm{C}$ for $48 \mathrm{~h}$.
\end{abstract}

Keywords: hydroxyapatite; biomaterial; milkfish.

(C) 2021 by the authors. This article is an open-access article distributed under the terms and conditions of the Creative Commons Attribution (CC BY) license (https://creativecommons.org/licenses/by/4.0/).

\section{Introduction}

An increase in biomaterial need leads to the development of various alternative biomaterial [1-4]. Bio-ceramics are safe, have no toxicity, and have superior compatibility [58]. Furthermore, it was used for a composite component amplifier. One of the most widely recognized bio-ceramics is hydroxyapatite (HAp). Milkfish is easy to find in Indonesia. In 2014, the total production of milkfish in Indonesia was 631125 tons, or $14.74 \%$ of total cultivated fish production [9]. The high cultivated production can be proportional to its waste. Milkfish bone waste can be produced up to $15 \mathrm{~kg}$ or approximately 5.4 tons per year. Bone waste contains high calcium compounds because the main elements of fish bones are calcium, phosphorus, and carbonate [10].

Calcium and phosphor are the main constituents of HAp [9]. Therefore, milkfish bones can be used as raw material in HAp synthesis. HAp is calcium phosphate-containing hydroxide and has a hexagonal structure with 200, 111, 002, 102, 210, 211, 112, 300, and 202 crystallographic planes at $22.01^{\circ}, 23.02^{\circ}, 26.06^{\circ}, 28.51^{\circ}, 29.22^{\circ}, 31.79^{\circ}, 32.32^{\circ}, 32.88^{\circ}$, and $34.55^{\circ}$ peaks, respectively $[11,12]$. HAp in fishbone can be utilized for bone regeneration, repair, fill, expansion, and reconstruction of bone tissue. HAp is a bioactive mineral apatite compound that has the potential to be used as a coating and implantation of composites. It has a similar structure and composition with inorganic components in hard tissues, such as bone 
and tooth structure minerals. Clinically, HAp had been used in the last 20 years ago because of its excellent properties.

HAp can be derived either from natural sources or by synthetic methods [13-16]. The synthetic methods include hydrothermal, liquid emulsion in membranes, precipitation, sol-gel and polymerization. However, these methods are complicated and have the side effect of ammonia. In addition, chemical methods require toxic chemicals and the reaction conditions have to be controlled. Microstructural HAp has been obtained from fish bones by thermal treatment [17], thermal decomposition [18], hydrothermal treatment [19], supercritical water processing of bovine bone, pork teeth and bones, extraction of human and squid teeth. For instance, Shi, Liu [20] had evaluated the effect of temperature on the isolation and characterization of HAp from fish bones.

The characteristics of HAp are bioactive, biocompatible, osteoconductive, non-toxic and non-immunogenic [21-25]. Several characterizations of HAP have been obtained, such as the chemical-physical characteristics of porous ceramic HAp [26], the electrical characteristics of ceramic-based HAp [27], and the mechanical characteristics of bioceramic-based porous HAp due to the influence of shape and pores [28]. In addition, HAp can also be used as an adsorbent to remove environmental pollution [29]. Considering this topic's significance, the current study proposed synthesizing HAp from milkfish bones using simple heat treatments.

\section{Materials and Methods}

\subsection{Material.}

The material used in this study is milkfish bones obtained from milkfish waste. Acetone $\left(\mathrm{CH}_{3} \mathrm{COCH}_{3}\right)$ and distilled water were used in the preparation of fishbone samples. In addition, 100 mesh sieves, drying oven (Model YNC-OVYENACO, China), digital balance (Type PW24, Adam Equipment, USA), mechanical milling (Model MDY-1000, FOMAC, China) and furnace were employed in this study.

\subsection{Fishbone preparation.}

First, the milkfish bones are boiled to remove the remaining sticky meat. The boiling was carried out at $80{ }^{\circ} \mathrm{C}$ for $2 \mathrm{~h}$. Then, the fishbone was cleaned and washed using distilled water. Furthermore, the fish bones were soaked in acetone solution for one h. Next, the prepared milkfish bones were dried at $160{ }^{\circ} \mathrm{C}$ for $48 \mathrm{~h}$.

\subsection{HAp synthesis.}

The dried milkfish bones were ground into particles. The extraction technique was carried out by heating at high temperatures). The sintering temperature variations were $600{ }^{\circ} \mathrm{C}$, $700{ }^{\circ} \mathrm{C}$, and $800{ }^{\circ} \mathrm{C}$ for $5 \mathrm{~h}$. The sintering process began with weighing $7 \mathrm{~g}$ of milkfish bone powder into a porcelain dish, then heating it in a furnace with an increase in heating of $20{ }^{\circ} \mathrm{C}$ per min. After achieving sintering temperature heating, the material was allowed to stand until the temperature drops back to room temperature. HAp powder product from milkfish bones has been obtained. It was packed in plastic and stored at room temperature before characterization. 


\subsection{Characterization.}

The functional groups of the HAp were investigated by Fourier transform infrared spectroscopy (FTIR). The spectra were recorded under a nitrogen atmosphere from 400 to 4000 $\mathrm{cm}^{-1}$ with a resolution of $4 \mathrm{~cm}^{-1}$ using an IFS 66 FTIR spectrometer (Bruker, Billerica, MA, USA). The X-ray diffraction (XRD) was analyzed using Bruker D8 X-ray diffractometer with $\mathrm{Cu}$ target and $\mathrm{K} \alpha$ radiation source $(\mathrm{x}=1.540598 \AA)$. Each sample was scanned in the range of 5 to $70^{\circ}(40 \mathrm{kV}, 30 \mathrm{~mA})$.

The yield and color of milkfish bone HAp powder were analyzed according to the study by Venkatesan and Kim [30]. The yield of milkfish bone HAp powder is the relative weight of fishbone powder before and after the thermal treatment and can be estimated as follows:

$\gamma=\frac{W_{f}}{W_{i}} \times 100 \%$

with $\gamma$ is the yield of HAp powder $(\%), W_{f}$ is the final weight $(\mathrm{g})$, and $W_{i}$ is the initial weight (g).

The color of the milkfish bone HAp powder was identified visually by comparing the fishbone powder samples before and after the sintering process.

\section{Results and Discussion}

\subsection{Yield percentage.}

HAp is extracted from milkfish bones and the yield results are tabulated in Table 1. The study found that the higher the sintering temperature produced, the smaller the yield. The decrease in yield during the sintering process is probably due to the loss of water content and organic matter in the fishbone powder. According to Venkatesan and Kim [30], two inflection points in fishbone powder were at a temperature of $100.5^{\circ} \mathrm{C}$ and $365.6^{\circ} \mathrm{C}$. This indicates the point of loss of water and organic matter. Similar results were shown by Pallela, Venkatesan [31], who stated that the inflection point can be observed at a temperature of $365.6{ }^{\circ} \mathrm{C}$. The study indicated a loss of collagen and other organic matter.

Table 1. Yield percentage and color of HAp from sintering process of Chanos chanos bone

\begin{tabular}{l|l|l|l|l|l} 
& Sample & $\begin{array}{l}\text { Sintering } \\
\text { Temperature } \\
\left({ }^{\circ} \mathbf{C}\right)\end{array}$ & $\begin{array}{l}\text { Weight } \\
\text { Before } \\
\text { Treatment } \\
(\mathbf{g})\end{array}$ & $\begin{array}{l}\text { Weight } \\
\text { After } \\
\text { Treatment } \\
(\mathbf{g})\end{array}$ & $\begin{array}{l}\text { Yield } \\
(\boldsymbol{\%})\end{array}$ \\
\hline A & Without sintering & - & - & - & Color \\
\hline B & 600 & 7.00 & 3.8505 & 55.00 & Yellow \\
\hline C & 700 & 7.02 & 3.7216 & 53.17 & Grey \\
\hline D & 800 & 7.01 & 3.6708 & 52.44 & White
\end{tabular}

At temperatures $200-300{ }^{\circ} \mathrm{C}$, the weight of the combined components of water and organic matter decreases slightly. Nevertheless, at a sintering temperature of $300-500{ }^{\circ} \mathrm{C}$, weight loss would be drastic due to the decomposition of organic materials, such as collagen, fat, and protein related to other bone components. At $600{ }^{\circ} \mathrm{C}$ sintering temperature, the only compound remaining was calcium phosphate. The reduction in sample weight at sintering temperature $600-800{ }^{\circ} \mathrm{C}$ ranged from $30-40 \%$. It was caused by the attachment between the collagen components, fat tissue, and protein.

Before the sintering process, the color of the fishbone powder was yellow. HAp is classified as an organic matter [31]. The yellow color can be turned black, brown, smelly, and 
white as the temperature increase. Figure 1 displayed that the bone powder is gray at $600{ }^{\circ} \mathrm{C}$ of sintering temperature and the fishbone powder is white at $700{ }^{\circ} \mathrm{C}$ and $800{ }^{\circ} \mathrm{C}$. The remaining organic compounds caused the gray color at low sintering temperatures $\left(600^{\circ} \mathrm{C}\right)$ in the form of carbon found in the fish bones. Fish had 30\% organic components and 60-70\% calcium phosphate and HAp components [32].

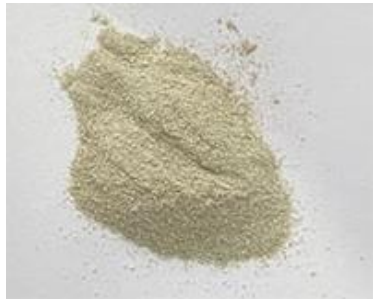

(a)

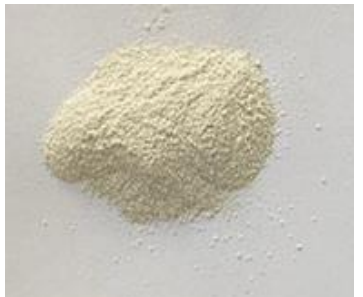

(b)

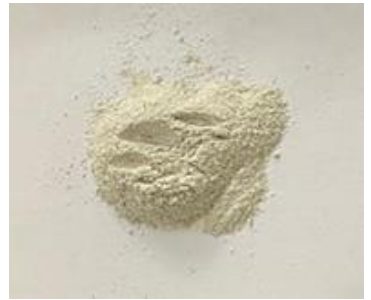

(c)

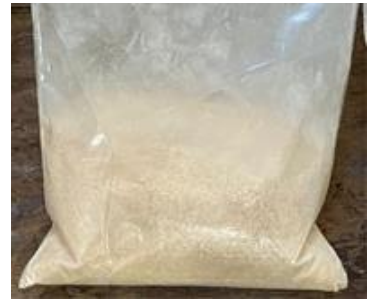

(d)

Figure 1. Fishbone powder color after the sintering process: (a) $600{ }^{\circ} \mathrm{C} ;$ (b) $700{ }^{\circ} \mathrm{C} ;(\mathbf{c}) 800{ }^{\circ} \mathrm{C}$; and (d) before the sintering process.

Ozawa and Suzuki [33] exhibited white samples at high temperatures (700-1000) ${ }^{\circ} \mathrm{C}$. It specified that the organic material was not degraded. In addition, the yield after sintering designated that HAp had a high level of purity. Similar studies demonstrated that yield values in the range of $60 \%$ or less were white, indicating purer HAp [30].

\subsection{Functional group of Hap.}

The functional group is a qualitative analysis to identify the constituent elements of milkfish bones through transmission absorption produced by FTIR. FTIR identification is based on changes in molecular vibrations caused by electrostatic modification of valence in alkanes, alkenes, arenas, amines, carboxyl and hydroxyl bonds [34]. The functional group of milkfish bones generally consists of two constituent elements, such as organic and inorganic. Each molecule has a certain energy in vibration. It depends on the atoms and the bonding strength connecting them. FTIR characterization is carried out to obtain valid information regarding the vibrations of phosphate, carbonate, and amide compounds to ensure the preparation of HAp compounds without the association of organic groups. $\mathrm{HAp}$ has $\mathrm{OH}^{-}, \mathrm{CO}_{3}{ }^{2}$, and $\mathrm{PO}_{4}{ }^{3-}$ groups $[35,36]$. Figure 2 shows the functional group characteristics of Hap without the sintering process.

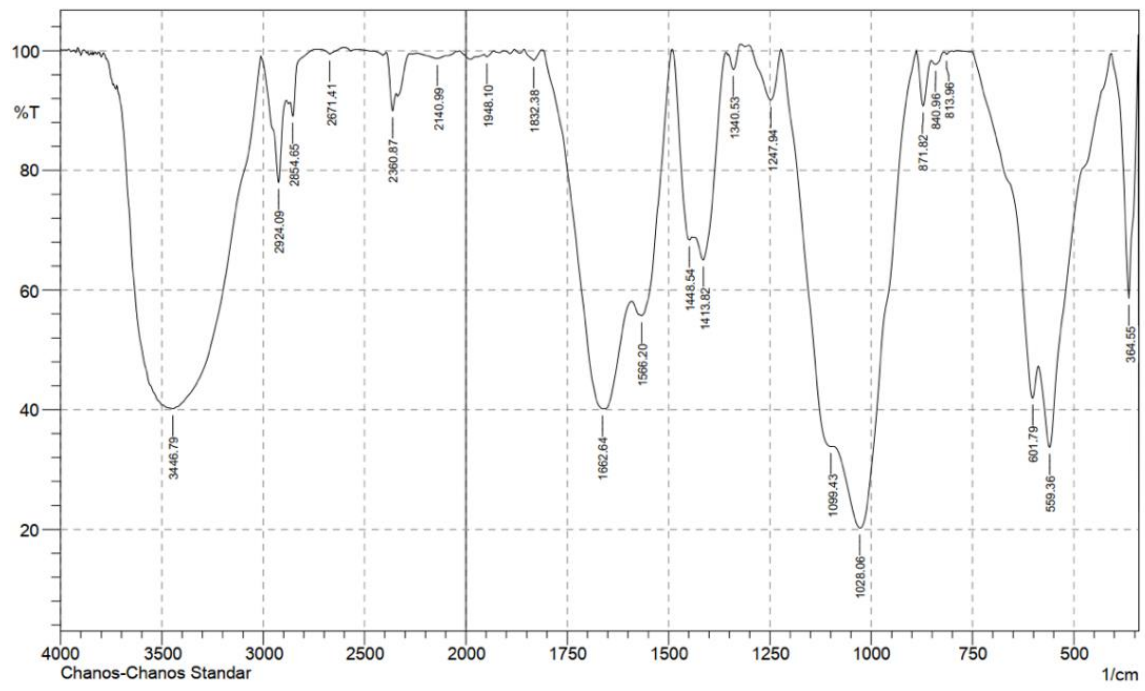

Figure 2. FTIR spectra of Chanos chanos without sintering process. 
The spectrum for samples with various sintering temperature variations, as shown in Figure 3, shows the presence of an $\mathrm{O}-\mathrm{H}$ group absorption band at wave number $3446 \mathrm{~cm}^{-1}$. Mondal, Mondal [37] represented that the $\mathrm{O}-\mathrm{H}$ group was detected in the wavenumber range of $3497 \mathrm{~cm}^{-1}$. Venkatesan and Kim [30] reported that the peaks detected at wavenumbers 3300$3600 \mathrm{~cm}^{-1}$ indicated the presence of a hydroxyl group. HAp contains an $\mathrm{O}-\mathrm{H}$ group, a $\mathrm{CO}_{3}{ }^{2-}$ group and $\mathrm{PO}_{4}{ }^{3-}$ group.

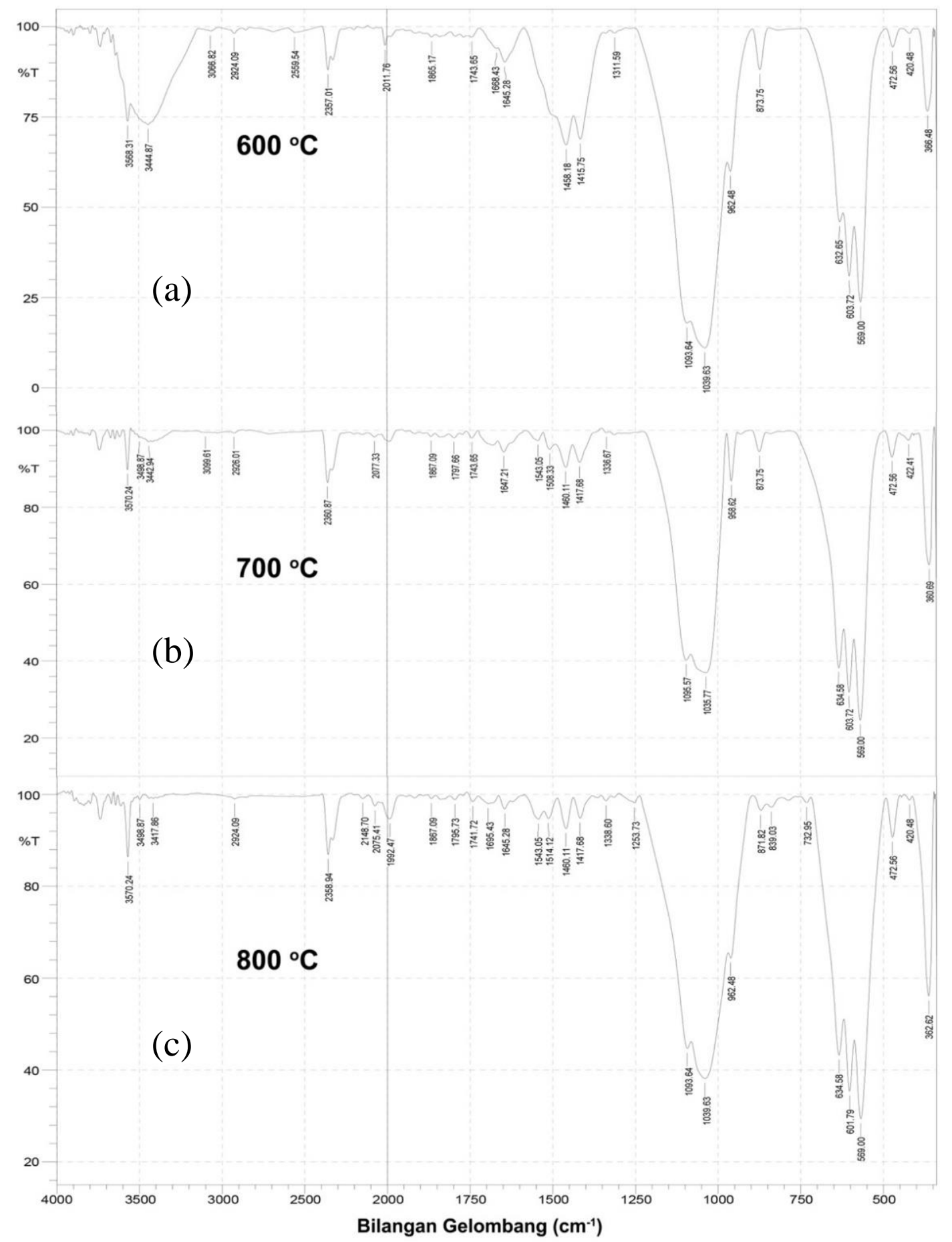

Figure 3. FTIR spectra of HAp at different sintering temperatures of (a) $600{ }^{\circ} \mathrm{C}$; (b) $700{ }^{\circ} \mathrm{C}$; (c) $800{ }^{\circ} \mathrm{C}$.

Without the sintering process, HAp has a phosphate group absorption band $\left(\mathrm{PO}_{4}{ }^{3-}\right)$ which vibrates asymmetric stretching at wavenumbers $1028-1099 \mathrm{~cm}^{-1}$ and vibrates bending at wavenumbers $559 \mathrm{~cm}^{-1}$ and $601 \mathrm{~cm}^{-1}$. At $600{ }^{\circ} \mathrm{C}$ sintering temperature, the absorption band of $\mathrm{PO}_{4}{ }^{3-}$ groups vibrates stretching asymmetry at wave number $1039-1093 \mathrm{~cm}^{-1}$ and vibrates 
bending at wave number $569-632 \mathrm{~cm}^{-1}$. At $700{ }^{\circ} \mathrm{C}$ sintering temperature, the $\mathrm{PO}_{4}{ }^{3-}$ group absorption band vibrates asymmetry stretching at a wavenumber $1035-1095 \mathrm{~cm}^{-1}$. At $800{ }^{\circ} \mathrm{C}$ sintering temperature, the absorption band of the $\mathrm{PO}_{4}{ }^{3-}$ group vibrates asymmetry stretching at the wave number 1039-1093 $\mathrm{cm}^{-1}$. Meanwhile, the absorption band of the phosphate group at sintering temperatures of $700{ }^{\circ} \mathrm{C}$ and $800{ }^{\circ} \mathrm{C}$ had a bending vibration at wave number 569-634 $\mathrm{cm}^{-1}$. The phosphate absorption band formed is asymmetrical, indicating that the HAp in the sample is crystalline [38].

Mondal, Mondal [37] mentioned that the first indication of the formation of HAp compounds is the formation of a complex at wave number $1000-1100 \mathrm{~cm}^{-1}$, vibrating stretching asymmetry for the phosphate group and vibrating bending symmetry at wave number 576.30 $\mathrm{cm}^{-1}$. In Figure 3, it can also be seen that the peak of the carbonate group has decreased with increasing sintering temperature. Similar results, Prabakaran and Rajeswari [35] showed that the decrease in the peak of the carbonate group ion occurs along with the increase in temperature used. For the synthesis results without sintering, the carbonate absorption band $\left(\mathrm{CO}_{3}{ }^{2-}\right)$ vibrated asymmetric stretching at wavenumbers $1413 \mathrm{~cm}^{-1}$ and $1448 \mathrm{~cm}^{-1}$. At a temperature of $600{ }^{\circ} \mathrm{C}$, carbonate absorption bands were detected at wavenumbers $1415 \mathrm{~cm}^{-1}$ and $1458 \mathrm{~cm}^{-1}$, while temperatures of $700{ }^{\circ} \mathrm{C}$ and $800{ }^{\circ} \mathrm{C}$ were detected at wavenumbers 1417 $\mathrm{cm}^{-1}$ and $1460 \mathrm{~cm}^{-1}$. Venkatesan and Kim [30] also know about the effect of temperature on the isolation and characterization of HAp from tuna bones. The study showed that the absorption bands of carbonate groups were detected at wavenumbers $1414 \mathrm{~cm}^{-1}$ and $1457 \mathrm{~cm}^{-}$ ${ }^{1}$. High sintering temperature results in high transmittance values.

Increasing the temperature could increase the intensity of the sharp peaks and could reduce the width of the peaks that indicated the removal organic matter process. Fishbones without heating process produced wide peaks with low intensity due to the extracellular matrix and protein fibers. The intensity of the infrared spectrum depended on the temperature during the sintering process [39]. Figure 3 presented that the increase in sintering temperature tended to increase the concentration of phosphate formed. It can be seen from the longer and steeper the phosphate groups on the FTIR results. The appearance of a phosphate group indicated that HAp in the sample had been formed [40]. High sintering temperature results in high transmittance values. Sample with a sintering temperature of $800^{\circ} \mathrm{C}$ had a higher transmittance value compared to temperatures of $600{ }^{\circ} \mathrm{C}$ and $700{ }^{\circ} \mathrm{C}$.

\subsection{Phase and crystallinity of HAp.}

Analysis using the XRD instrument aims to determine the phase and crystallinity. Several HAps were analyzed, such as HAp without sintering and with sintering $600{ }^{\circ} \mathrm{C}-800$ ${ }^{\circ} \mathrm{C}$. The phase analysis aimed to determine the phase of milkfish bones and the shift in the peak of the HAp. Crystallinity analysis aims to determine the effect of sintering temperature on crystallinity. Crystallinity indicates the amount of crystal content in a material by comparing the area of the crystal with the total area of amorphous and crystalline crystals. The XRD diffraction pattern, as shown in Figure 4 showed that the hydroxyapatite phase dominated the peaks of the XRD pattern. Based on JCPDS no. 09-0432 HAp phase has 4 typical peaks, such as in the region of $31.77^{\circ}, 32.19^{\circ}, 32.90^{\circ}$ and $34.05^{\circ}$ [41].

There are four phases contained in fish bones, such as apatite carbonate type A (AKA) with the molecular formula $\left(\mathrm{Ca} 10\left(\mathrm{PO}_{4}\right)_{6}\left(\mathrm{CO}_{3}\right)_{2}\right)$, apatite carbonate type $\mathrm{B}(\mathrm{AKB})$ with the molecular formula $\left(\mathrm{Ca}_{10}\left(\mathrm{PO}_{4}\right)_{3}\left(\mathrm{CO}_{3}\right)_{3}(\mathrm{OH})_{2}\right)$, tricalcium phosphate $(\mathrm{TKF})$ with the molecular formula $\left(\mathrm{Ca}_{3}\left(\mathrm{PO}_{4}\right)_{2}\right.$ and octa calcium phosphate $(\mathrm{OKF})$ with the molecular formula 


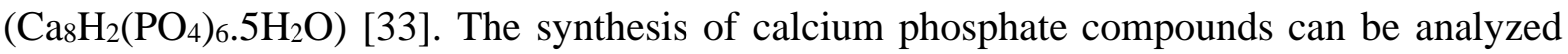
using XRD, while the determination of the emerging phase refers to (Joint Committee on Powder Diffraction Standards) (JCPDS) data. The X-ray diffraction pattern of milkfish bone powder at sintering temperature can be comprehensively seen in Figure 4.

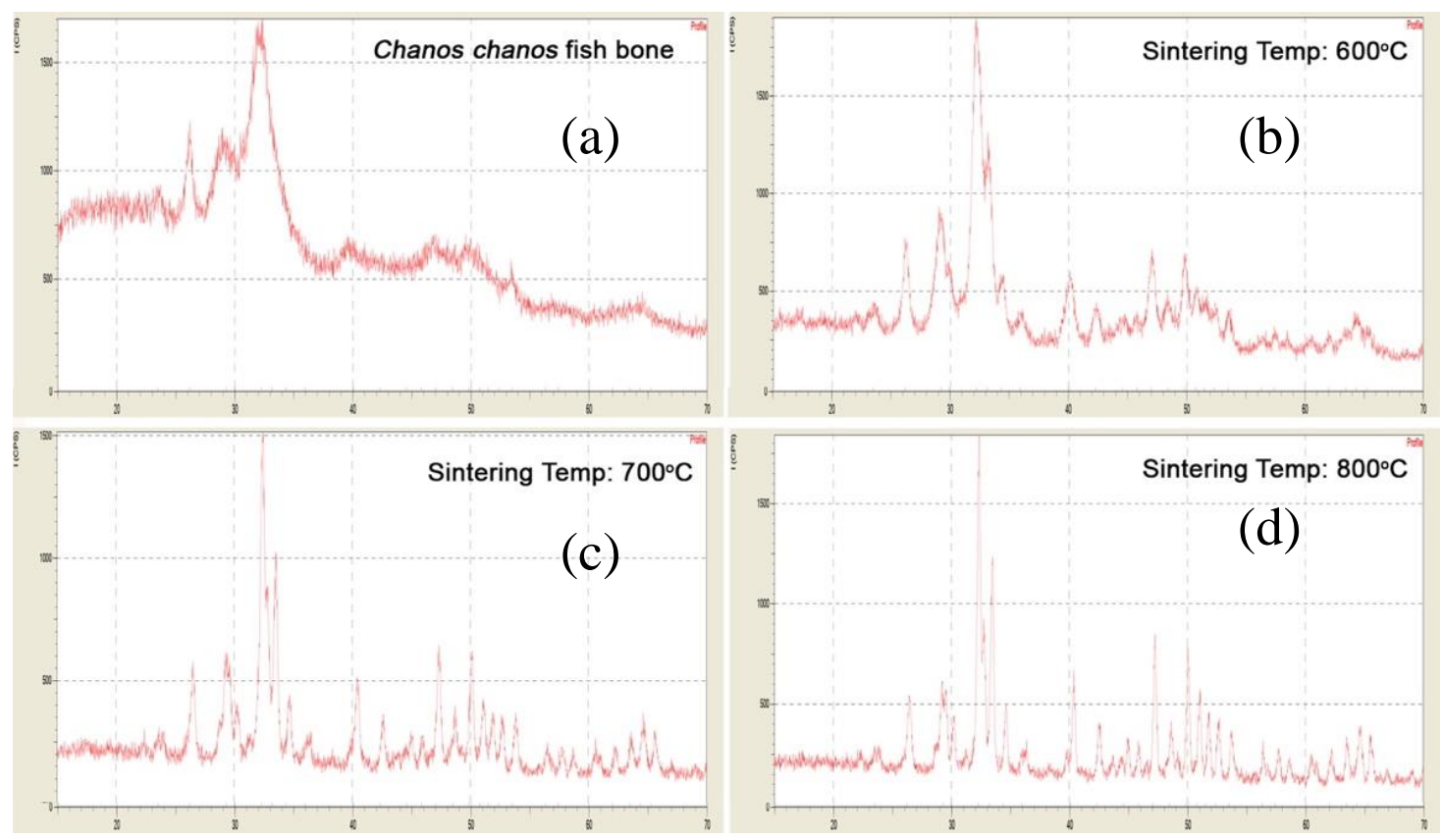

Figure 4. The x-ray diffraction pattern of HAp at different sintering temperatures of (a) without sintering; (b) $600{ }^{\circ} \mathrm{C}$; (c) $700{ }^{\circ} \mathrm{C} ;$ (d) $800{ }^{\circ} \mathrm{C}$.

HAp products with high crystallinity properties were formed at the sintering temperature. According to Askari, Yousefpour [42], the HAp phase was characterized at high intensity at 2 theta values, such as $31.773^{\circ}, 32.196^{\circ}, 32.902^{\circ}$ and $34.048^{\circ}$. XRD analysis exposed that there was a change in the intensity of the peaks on the diffractogram. The effect of temperature is closely related to the level of crystallinity of the sample. Each temperature has different peaks of crystallinity intensity. Rodríguez-Lugo, Karthik [43] mentioned that the crystallinity was higher by increasing the temperature of the sintering process. In general, this paper enhances the knowledge on the exploration of natural resources or wastes for various future engineering applications [44-50].

\section{Conclusions}

This study aimed to propose the synthesis of HAp from milkfish bones by using simple heat treatments. Well-crystallized HAp can be synthesized by thermal treatment at $160{ }^{\circ} \mathrm{C}$ for $48 \mathrm{~h}$. This study also found that the yield percentages were more than $50 \%$. The crystallinity of HAp powder can be improved by increasing the temperature of the sintering process.

\section{Funding}

This research was funded by Universitas Kristen Indonesia Toraja.

\section{Acknowledgments}

The authors thank the Universitas Kristen Indonesia Toraja and Universitas Nahdlatul Ulama Surabaya for facilitating the research work. 


\section{Conflicts of Interest}

\section{The authors declare no conflict of interest.}

\section{References}

1. Nikmatin, S.; Syafiuddin, A.; Kueh, A.B.H.; Purwanto, Y.A., Effects of nanoparticle filler on thermophysical properties of rattan powder-filled polypropylene composites. Jur. Tek., 2015. 77, 181-187, https://doi.org/10.11113/jt.v77.6415.

2. Nikmatin, S.; Syafiuddin, A.; Irwanto, D.A.Y., Properties of oil palm empty fruit bunch-filled recycled acrylonitrile butadiene styrene composites: Effect of shapes and filler loadings with random orientation. BioResources, 2016. 12, 1090-1101, https://doi.org/10.15376/biores.12.1.1090-1101.

3. Nikmatin, S.; Syafiuddin, A.; Hong Kueh, A.B.; Maddu, A., Physical, thermal, and mechanical properties of polypropylene composites filled with rattan nanoparticles. J. App. Res. Technol., 2017. 15, 386-395, https://doi.org/10.1016/j.jart.2017.03.008.

4. Nikmatin, S.; Hermawan, B.; Irmansyah, I.; Indro, M.N.; Kueh, A.B.H.; Syafiuddin, A., Evaluation of the performance of helmet prototypes fabricated from acrylonitrile butadiene styrene composites filled with natural resource. Materials, 2019. 12, 1-12, https://doi.org/10.3390/ma12010034.

5. Goh, K.W.; Wong, Y.H.; Ramesh, S.; Chandran, H.; Krishnasamy, S.; Ramesh, S.; Sidhu, A.; Teng, W.D., Effect of $\mathrm{pH}$ on the properties of eggshell-derived hydroxyapatite bioceramic synthesized by wet chemical method assisted by microwave irradiation. Ceram. Int., 2021. 47, 8879-8887, https://doi.org/10.1016/j.ceramint.2020.12.009.

6. Es-saddik, M.; Laasri, S.; Taha, M.; Laghzizil, A.; Guidara, A.; Chaari, K.; Bouaziz, J.; Hajjaji, A.; Nunzi, J.M., Effect of the surface chemistry on the stability and mechanical properties of the Zirconia$\begin{array}{lllll}\text { Hydroxyapatite } \quad \text { bioceramic. } & \text { Surf. } & \text { Interfaces, } & \mathbf{2 0 2 1} & 23,\end{array}$ https://doi.org/10.1016/j.surfin.2021.100980.

7. Xu, S.; Wu, Q.; Guo, Y.; Ning, C.; Dai, K., Copper containing silicocarnotite bioceramic with improved mechanical strength and antibacterial activity. Mater. Sci. Eng. C Mater. Biol. Appl., 2021. 118, 111493, https://doi.org/10.1016/j.msec.2020.111493.

8. Bazin, T.; Magnaudeix, A.; Mayet, R.; Carles, P.; Julien, I.; Demourgues, A.; Gaudon, M.; Champion, E., Sintering and biocompatibility of copper-doped hydroxyapatite bioceramics. Ceram. Int., 2021. 47, 1364413654, https://doi.org/10.1016/j.ceramint.2021.01.225.

9. Herawati, V.E.; Fuad, A.; Pinandoyo, P.; Hutabarat, J.; Darmanto, Y.; Wirasatriya, A.; Nugroho, D.; Rismaningsih, N.; Radjasa, O.K., Maggot Meal (Hermetia illucens) substitution on fish meal as source of animal protein to growth, feed utilization efficiency, and survival rate of milkfish (Chanos chanos). Hayati, 2020. 27, 154-154, https://doi.org/10.4308/hjb.27.2.154.

10. Asadollahzadeh, M.; Rabiee, S.M.; Salimi-Kenari, H., In vitro apatite formation of calcium phosphate composite synthesized from fish bone. Int. J. Appl. Ceram. Technol., 2019. 16, 1969-1978, https://doi.org/10.1111/ijac.13297.

11. Sharifianjazi, F.; Esmaeilkhanian, A.; Moradi, M.; Pakseresht, A.; Asl, M.S.; Karimi-Maleh, H.; Jang, H.W.; Shokouhimehr, M.; Varma, R.S., Biocompatibility and mechanical properties of pigeon bone waste extracted natural nano-hydroxyapatite for bone tissue engineering. Mater. Sci. Eng. B, 2021. 264, 114950, https://doi.org/10.1016/j.mseb.2020.114950.

12. Nicoara, A.I.; Neacsu, I.A.; Ene, V.L.; Vasile, B.S.; Ficai, A.; Andronescu, E., Hydroxyapatite/carbon based biocomposite scaffolds as prospective materials for bone tissue engineering. UPB Sci. Bull. Ser. B Chem. Mater. Sci, 2019. 81, 107-120,

13. Ali, A.F.; Alrowaili, Z.A.; El-Giar, E.M.; Ahmed, M.M.; El-Kady, A.M., Novel green synthesis of hydroxyapatite uniform nanorods via microwave-hydrothermal route using licorice root extract as template. Ceram. Int., 2021. 47, 3928-3937, https://doi.org/10.1016/j.ceramint.2020.09.256.

14. Varadavenkatesan, T.; Vinayagam, R.; Pai, S.; Kathirvel, B.; Pugazhendhi, A.; Selvaraj, R., Synthesis, biological and environmental applications of hydroxyapatite and its composites with organic and inorganic coatings. Prog. Org. Coat., 2021. 151, 106056, https://doi.org/10.1016/j.porgcoat.2020.106056.

15. Sultana, S.; Hossain, M.S.; Mahmud, M.; Mobarak, M.B.; Kabir, M.H.; Sharmin, N.; Ahmed, S., UVassisted synthesis of hydroxyapatite from eggshells at ambient temperature: cytotoxicity, drug delivery and bioactivity. RSC Adv., 2021. 11, 3686-3694, https://doi.org/10.1039/D0RA09673C.

16. Neacsu, I.A.; Serban, A.P.; Nicoara, A.I.; Trusca, R.; Ene, V.L.; Iordache, F., Biomimetic composite scaffold based on naturally derived biomaterials. Polymers, 2020. 12, 1161, https://doi.org/10.3390/polym12051161.

17. Yelten-Yilmaz, A.; Yilmaz, S., Wet chemical precipitation synthesis of hydroxyapatite (HA) powders. Ceram. Int., 2018. 44, 9703-9710, https://doi.org/10.1016/j.ceramint.2018.02.201.

18. Malla, K.P.; Regmi, S.; Nepal, A.; Bhattarai, S.; Yadav, R.J.; Sakurai, S.; Adhikari, R., Extraction and characterization of novel natural hydroxyapatite bioceramic by thermal decomposition of waste ostrich bone. Int. J. Biomater., 2020. 2020, 1690178, https://doi.org/10.1155/2020/1690178. 
19. Kumar, G.S.; Karunakaran, G.; Girija, E.K.; Kolesnikov, E.; Minh, N.V.; Gorshenkov, M.V.; Kuznetsov, D., Size and morphology-controlled synthesis of mesoporous hydroxyapatite nanocrystals by microwaveassisted hydrothermal method. Ceram. Int., 2018. 44, 11257-11264, https://doi.org/10.1016/j.ceramint.2018.03.170.

20. Shi, P.; Liu, M.; Fan, F.; Yu, C.; Lu, W.; Du, M., Characterization of natural hydroxyapatite originated from fish bone and its biocompatibility with osteoblasts. Mater. Sci. Eng. C Mater. Biol. Appl., 2018. 90, 706712, https://doi.org/10.1016/j.msec.2018.04.026.

21. Jaber, H.L.; Hammood, A.S.; Parvin, N., Synthesis and characterization of hydroxyapatite powder from natural Camelus bone. J. Aust. Ceram. Soc., 2018. 54, 1-10, https://doi.org/10.1007/s41779-017-0120-0.

22. Ding, R.; zhang, J.; Koushki, E.; Tayebee, R.; Ding, X., Nonlinear photoacoustic and optical properties of hydroxyapatite and calcium phosphate. Towards a new method for the densitometry of bones. Optik, 2021. 226, 165922, https://doi.org/10.1016/j.ijleo.2020.165922.

23. Asgari, N.; Rajabi, M., Enhancement of mechanical properties of hydroxyapatite coating prepared by electrophoretic deposition method. Int. J. Appl. Ceram. Technol., 2021. 18, 147-153, https://doi.org/10.1111/ijac.13638.

24. Du, M.; Chen, J.; Liu, K.; Xing, H.; Song, C., Recent advances in biomedical engineering of nanohydroxyapatite including dentistry, cancer treatment and bone repair. Compos. Part B Eng., 2021. 215, 108790, https://doi.org/10.1016/j.compositesb.2021.108790.

25. Ahangari, M.; Johar, M.H.; Saremi, M., Hydroxyapatite-carboxymethyl cellulose-graphene composite coating development on AZ31 magnesium alloy: Corrosion behavior and mechanical properties. Ceram. Int., 2021. 47, 3529-3539, https://doi.org/10.1016/j.ceramint.2020.09.197.

26. Li, J.; Wu, M.; Du, H.; Wang, B.; Li, Y.; Huan, W., Highly effective catalytic reduction of nitrobenzene compounds with gold nanoparticle-immobilized hydroxyapatite nanowire-sintered porous ceramic beads. New J. Chem., 2021. 45, 4601-4610, 10.1039/D0NJ06209J.

27. Reis Lavagnini, I.; Campos, J.V.; Storion, A.G.; Lobo, A.O.; Raj, R.; Maria de Jesus Agnolon Pallone, E., Influence of flash sintering on phase transformation and conductivity of hydroxyapatite. Ceram. Int., 2021. 47, 9125-9131, https://doi.org/10.1016/j.ceramint.2020.12.036.

28. Veljović, D.; Jančić-Hajneman, R.; Balać, I.; Jokić, B.; Putić, S.; Petrović, R.; Janaćković, D., The effect of the shape and size of the pores on the mechanical properties of porous HAP-based bioceramics. Ceram. Int., 2011. 37, 471-479, https://doi.org/10.1016/j.ceramint.2010.09.014.

29. Ma, J.; Xia, M.; Zhu, S.; Wang, F., A new alendronate doped hap nanomaterial for pb2+, cu2+ and cd2+ effect absorption. J. Hazard. Mater., 2020. 400, 123143, https://doi.org/10.1016/j.jhazmat.2020.123143.

30. Venkatesan, J.; Kim, S.K., Effect of temperature on isolation and characterization of hydroxyapatite from tuna (thunnus obesus) bone. Materials, 2010. 3, 4761-4772, https://doi.org/10.3390/ma3104761.

31. Pallela, R.; Venkatesan, J.; Kim, S.K., Polymer assisted isolation of hydroxyapatite from Thunnus obesus bone. Ceram. Int., 2011. 37, 3489-3497, https://doi.org/10.1016/j.ceramint.2011.06.004.

32. Kim, S.-K.; Mendis, E., Bioactive compounds from marine processing byproducts - A review. Food Res. Int., 2006. 39, 383-393, https://doi.org/10.1016/j.foodres.2005.10.010.

33. Ozawa, M.; Suzuki, S., Microstructural development of natural hydroxyapatite originated from fishbone waste through heat treatment. J. Am. Ceram. Soc., 2002. 85, 1315-1317, https://doi.org/10.1111/j.11512916.2002.tb00268.x.

34. Berthomieu, C.; Hienerwadel, R., Fourier transform infrared (FTIR) spectroscopy. Photosynthesis Research, 2009. 101, 157-170, https://doi.org/10.1007/s11120-009-9439-x.

35. Prabakaran, K.; Rajeswari, S., Development of hydroxyapatite from natural fish bone through heat treatment. Trends Biomater. Artif. Organs, 2006. 20, 20-23,

36. Neacsu, I.A.; Arsenie, L.V.; Trusca, R.; Ardelean, I.L.; Mihailescu, N.; Mihailescu, I.N.; Ristoscu, C.; Bleotu, C.; Ficai, A.; Andronescu, E., Biomimetic collagen/ $\mathbf{z n}^{2+}$-substituted calcium phosphate composite coatings on titanium substrates as prospective bioactive layer for implants: A comparative study spin coating vs. MAPLE. Nanomaterials, 2019. 9, 692, https://doi.org/10.3390/nano9050692.

37. Mondal, S.; Mondal, B.; Dey, A.; Mukhopadhyay, S.S., Studies on processing and characterization of hydroxyapatite biomaterials from different bio wastes. J. Miner. Mater. Charact. Eng, 2012. 11, 55-67, https://doi.org/10.4236/jmmce.2012.111005.

38. Wang, Y.; Li, R.; Liu, W.; Cheng, L.; Jiang, Q.; Zhang, Y., Exploratory of immobilization remediation of hydroxyapatite (HAP) on lead-contaminated soils. Environ. Sci. Pollut. Res., 2019. 26, 26674-26684, https://doi.org/10.1007/s11356-019-05887-4.

39. Prabakaran, K.; Rajeswari, S., Spectroscopic investigations on the synthesis of nano-hydroxyapatite from calcined eggshell by hydrothermal method using cationic surfactant as template. Spectrochim. Acta. A Mol. Biomol. Spectrosc., 2009. 74, 1127-1134, https://doi.org/10.1016/j.saa.2009.09.021.

40. Yu, W.; Sun, R.; Guo, Z.; Wang, Z.; He, Y.; Lu, G.; Chen, P.; Chen, K., Novel fluoridated hydroxyapatite/mao composite coating on az31b magnesium alloy for biomedical application. Appl. Surf. Sci., 2019. 464, 708-715, https://doi.org/10.1016/j.apsusc.2018.09.148. 
41. Liu, Y.-C.; Lin, G.S.; Wang, J.-Y.; Cheng, C.-S.; Yang, Y.-C.; Lee, B.-S.; Tung, K.-L., Synthesis and characterization of porous hydroxyapatite coatings deposited on titanium by flame spraying. Surf Coat Tech, 2018. 349, 357-363, https://doi.org/10.1016/j.surfcoat.2018.06.010.

42. Askari, N.; Yousefpour, M.; Rajabi, M., Determination of the optimum amount of iodine in electrophoretic deposition of hydroxyapatite (HA) nanoparticles. J. Aust. Ceram. Soc., 2020. 56, 1053-1059, https://doi.org/10.1007/s41779-020-00450-8.

43. Rodríguez-Lugo, V.; Karthik, T.V.K.; Mendoza-Anaya, D.; Rubio-Rosas, E.; Villaseñor Cerón, L.S.; ReyesValderrama, M.I.; Salinas-Rodríguez, E., Wet chemical synthesis of nanocrystalline hydroxyapatite flakes: effect of $\mathrm{pH}$ and sintering temperature on structural and morphological properties. R. Soc. Open Sci., 2018. 5, 180962, https://doi.org/10.1098/rsos.180962.

44. Syafiuddin, A.; Salmiati, S.; Hadibarata, T.; Kueh, A.B.H.; Salim, M.R., Novel weed-extracted silver nanoparticles and their antibacterial appraisal against a rare bacterium from river and sewage treatment plan. Nanomaterials, 2018. 8, 1-17, https://doi.org/10.3390/nano8010009.

45. Syafiuddin, A.; Salmiati, S.; Hadibarata, T.; Kueh, A.B.H.; Salim, M.R.; Zaini, M.A.A., Silver nanoparticles in the water environment in Malaysia: Inspection, characterization, removal, modeling, and future perspective. Sci. Rep., 2018. 8, 1-15, https://doi.org/10.1038/s41598-018-19375-1.

46. Mostafa, A.A.-F.; Elshikh, M.S.; Al-Askar, A.A.; Hadibarata, T.; Yuniarto, A.; Syafiuddin, A., Decolorization and biotransformation pathway of textile dye by Cylindrocephalum aurelium. Bioprocess Biosyst. Eng., 2019. 42, 1483-1494, https://doi.org/10.1007/s00449-019-02144-3.

47. Nurul Aini, A.; Al Farraj, D.A.; Endarko, E.; Rubiyanto, A.; Nur, H.; Al Khulaifi, M.M.; Hadibarata, T.; Syafiuddin, A., A new green method for the synthesis of silver nanoparticles and their antibacterial activities against gram-positive and gram-negative bacteria. J. Chin. Chem. Soc., 2019. 66, 705-712, https://doi.org/10.1002/jccs.201800412.

48. Syafiuddin, A.; Salmiati, S.; Hadibarata, T.; Salim, M.R.; Kueh, A.B.H.; Suhartono, S., Removal of silver nanoparticles from water environment: Experimental, mathematical formulation, and cost analysis. Water Air Soil Pollut., 2019. 230, 102-117, https://doi.org/10.1007/s11270-019-4143-8.

49. Syafiuddin, A.; Fulazzaky, M.A.; Salmiati, S.; Kueh, A.B.H.; Fulazzaky, M.; Salim, M.R., Silver nanoparticles adsorption by the synthetic and natural adsorbent materials: an exclusive review. Nano. Env. Engg., 2020. 5, 1-18, https://doi.org/10.1007/s41204-019-0065-3.

50. Syafiuddin, A.; Fulazzaky, M.A., Decolorization kinetics and mass transfer mechanisms of Remazol Brilliant Blue R dye mediated by different fungi. Biotechnol. Rep., 2021. 29, e00573, https://doi.org/10.1016/j.btre.2020.e00573. 